\title{
HOW TO VISUALIZE TIME, TENSE AND ASPEC'T?
}

\section{COMMENT VISUALISER LE TEMPS E' L'ASPECT ?}

\author{
Gérard LIGOZAT - Michael ZOCK \\ LIMSI, Langage \& Cognition \\ B.P. 133, 91403 Orsay Cedex / France \\ courrier électronique : ligozat @ limsi.fr, ou, zock @ limsi.fr
}

Nous allons décrire ci-dessous une extension d'un système interactif de génération de phrases. Après une description de SWIM,-acronyme de See What I Mean?- nous allons discuter la façon dont on communique au système des notions relatives au temps et à l'aspect.

Avec SWIM nous poursuivons trois objectifs : (a) assister un étudiant dans l'apprentissage d'une langue, plus précisément aider l'apprenant à passer des idées aux phrases (production du langage); (b) visualiser la relation sens-forme.; (c) fournir un environnement voisin des conditions dans lesquelles on apprend naturellement une langue.

Savoir parler une langue n'est pas inné, c'est le résultat d'un apprentissage. Selon le cadre on parle d'apprentissage naturel (on apprend dans le pays même où est utilisée cette langue) ou d'apprentissage institutionnel (enseignement). Une différence fondamentale entre les deux types d'apprentissage se situe au niveau du contrôle. Dans un cas l'apprenant est act if (apprentissage naturel), - il utilise la parole pour résoudre un problème le concernant (il cherche à obtenir des informations, il veut vérifier quelque chose, etc.) - tandis que dans l'autre cas il est essentiellement réact $i f$, c'est-à-dire qu'il ne parle que lorsqu'on le lui demande.

L'inconvénient majeur de 1 'apprentissage naturel est lié au fait que l'apprenant se trouve dans des situations où tout change constamment : la situation discursive, les buts ou les intentions de communication, les contenus et les formes linguistiques correspondantes. Cela est normal, car l'objectif est la communication faire passer un message en vue d'un but donné - et non la fixation, l'explication ou l'illustration systématique d'un point précis de la langue.

Quant à l'apprentissage dans un contexte scolaire (enseignement), les inconvénients en sont les suivants: (a) la situation est artificielle (on s'exerce pour apprendre la langue et non pour communiquer un message en vue d'un but donné); (b) le professeur ignore généralement la nature des besoins de l'élève. Si l'élève sait ce qu'il. veut dire, en revanche, il ignore souvent conment le dire. Quant au professeur, il sait comment le dire, mais il ignore ce que veut dire l'étudiant.

Pour résoudre ce problème de communication entre le professeur et l'étudiant nous avons conçu un système où l'élève peut poser des questions et où le professeur répond. On notera, que c'est l'étudiant qui a l'initiative du dialogue. C'est lui qui pose des questions, et il les pose en fonction de ses besoins.

A l'heure actuelle le système a plusieurs faiblesses et un des grands problèmes est celui de l'interface conceptuelle : comment lui communiquer le contenu du message, puisqu'on ne parle pas encore cette langue?

Nous montrons dans la deuxième partie de ce papier la façon dont l'élève communique des informations relatives au temps et a l'aspect. Ces informations sont délicates à transmettre pour au moins trois raisons: (a) il n'y a pas d'isomorphie entre les temps conceptuels et les temps grammaticaux (le "présent" peut aussi bien exprimer des événements qui ont eu lieu que des événements qui vont avoir lieu); (b) il n'y a pas de correspondance stricte entre les temps des différentes langues (c) la terminologie utilisée dans les manuels est trop abstraite. Elle pose des problèmes d'une manière générale, et à plus forte raison lorsque la catégorie métalinguistique utilisée n'a pas de correspondant dans la langue cible (le passé simple, par exemple, n'existe pas dans toutes les langues).

Partant des travaux de Reichenbach et de Vendler nous avons conçu un langage icônique pour communiquer les informations relatives au temps. Pour ce faire, nous avons complété leurs idées tout en les rendant plus accessibles à l'utilisateur (méta) linguistiquement innocent.

Mots clefs : entrée conceptuelle, génération de phrases, relations forme-sens, EIAO 


\section{Introduction}

The major goal of the system described here is to provide a natural envirorment 1 for lcarning to produce sentences in French. In order to achieve this goal, we have integrated the student into the process. He should be active rather than reactive, that is, he should talk not only when being asked. After all, he knows what he wants to say, what he lacks are the means of translating his thoughts into language.

SWIM $^{2}$ is an exploratory environment which has been built to simulate natural learning. The student asks the questions and the system answers them. Any of the following questions could occur in a natural setting : 3

1) How does one say idea?

2) Can one say linguistic form?

3) How should one say idea?

4) Why does one say form-1 and not form-2 ?

5) What would happen if conceptual modification?

6) What would happen if syntactic modification?

7) What would happen if word $y$ instead of word $x$ ?

8) What is the difference between form $x$ and form $y$ ?

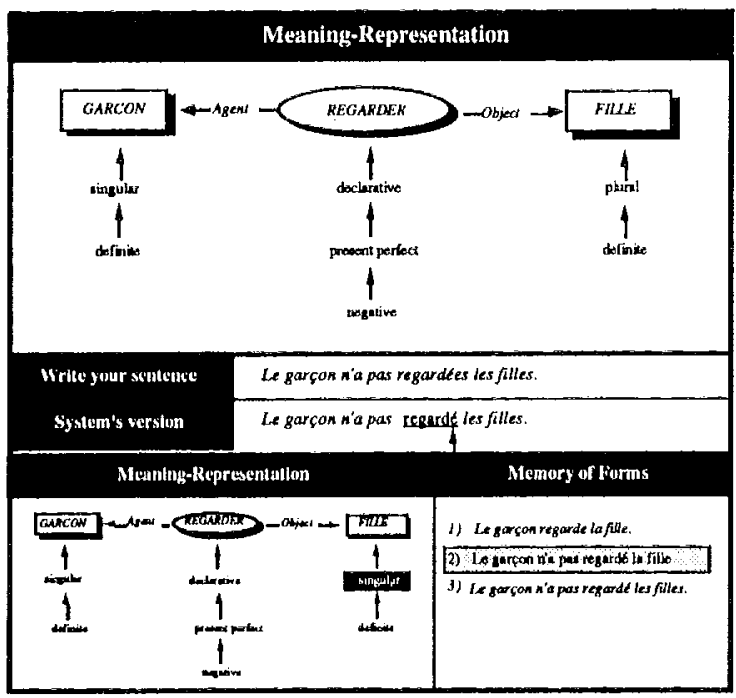

Figure 1

1 A computerized learning environment is said to be natural if the transfer of knowledge is achieved essentially in the same way as could be the case between two human agents, where a learner (child, student) asks questions and the teacher (native speaker, parent/teacher) answers them.

2 SWIM is the acronym of See What I Mean? It has been conceived by Michael Zock and implemented by A. Laroui on a Machitosh.

3 For the time being only the first and last four types of questions are implemented for a small subset of French (simple sentences).
The first communication-mode (how does one say <ideas?) raises an interesting problem : how to tell the computer what one wants to say (message). The fundamental question here is in what terms to code thought and access it. Obviously, there are several ways. One could ask in another natural language (translation), one could use images, or one could use some form of metalanguage.

In this paper we discuss some of the problems that arise by using a metalanguage. We then show how a special category of thought, tense, can be communicated by using a hybrid form of representation. But, before doing so let us give a short description of the system. For more details $\sec [29,30,31]$.

\section{Description of the system}

The dialogue is initiated by specifying the communication mode. Let us suppose that the user had started with the first question: How does one say <idea> ? In that case the system presents a menu (type hierarchy) from which the user has to choose:

Speech act : statement, question, command Actions - processes: taxonomy of verbs tense : present, past, future, etc.

Discourse objects : taxonomy of nouns number : singular, plural

communic, status : definite, indefinite, Attributes: taxonomy of attributes

By choosing specific values from a set of alternatives, the user tells the system what he wants to say. ${ }^{4}$ As the dialogue develops, the system builds the underlying meaning in the form of a semantic nctwork. It then invites the user to try to express this meaning, after which it outputs its own form.

As one can see from Figure 1, the screen is divided into five parts. The large window at the top represents the underlying meaning of the message a student is trying to convey. The next two windows contain respectively the user's attempt to express this meaning and the system's version. Possible mismatches between these two versions are highlighted on the screen. This allows the system to draw the student's attention to errors. Actually, by looking at Figure 1 you can see that the student made a mistake in the verb agreement "regarde". Finally, the two windows at the bottom represent, from left to right, a snapshot of the system's memory of meaning and the user's memory of form . The former is a device to display, hence to recall the underlying conceptual representation of a specific sentence chosen from the memory of form window, whereas the latter is an incrementally built database (trace) of all the sentences encountered so far.

The idea behind this separation is to allow the user to make a contrastive analysis of meaning and form between

4 For more details concening the interface controlling the conceptual input (What to say-component), see Zock (1991). 
two sentences. 5 Choosing a sentence in the memory of: fonm window gives a representation of the sentence's meaning in the memory of meaning window. By comparing the surface form and the underlying meaning of two sentences, the user can appreciate the relationship between meaning and form. The critical feature, the one that is responsible for the difference of form, is highlighted by the system. In our example it is the value "singular".

Past this point, the user has various options : either he continues in the basic communication inode (How does one say <ideas ?), or he changes the kind of question he wants to ask. Let us suppose that he wants to build a completely different sentence. In this case he could either go through the whole routine, which is quite cumbersome, or he could perform the conceptunl changes directely on the graph. Obviously, this latter nethod is much faster, 6

Actually, everything you sec on the graph, except deepcase relations, is considered by the system as a variable whose value may be changed directely by the user. In order to do so, he clicks on auy of the shown attributes (verb, tense, mode, ete.) and chooses a new value. For example, if he clicks on the verb "regarder" (to watch) the system answers by displaying a list of candidates from which we must choose. By clicking on the feature "present", the system shows different values (present, past, future, etc.) of the variable "tense", etc. Liverytime the system is given some piece of information it will change the meaning representation accordingly and, if asked, output the corresponding forin. For example, if one started from sentence (a) asking the system to change the number of the direct object from "singular" to "plural" it would produce (b). If one asked to change the tense from "simple past" to "present perfect", it would produce (c), etc.

a) Le garçon regarda ha fille (the boy watched the firl)

b) Le garçon regarda les filles (the boy watched the girls)

c) Le garçon a gegardé les filles (the boy has watched the girls)

As one can see, this method allows for local as well as for global changes. Actually, the dialogue described corresponds to the communication mode 5. If one changes only one value each time, asking the system to tell right away how this meaning change is reflected in form, one can very quickly build and explore a large search space. It should be noted, that this kind of dialogue between tian and machine is much faster and

5 See communication mode 8 : What is the difference between $<$ form $x>$ and $<$ form $y>$ ?

6 Actually, that is one of the major advantages of abstract representations compared to, let us say, icons. Another advantage is that this kind of representation shows onnline how conceptual or pragmatic choices affect the intermediate structure, hence more or less directly the final form. In consequence, by displaying on-line the way how the intermediate structure changes after each choice, we have a means of moving from a black box to a glass box. The former only shows how changes of the input (conceptual choices) are reflected in the output, whereas the latter also shows how discourse choices (topicalisation, word choice, etc.) affect the intermediate levels. less tedious than it would be between a student and a teacher. The change of meaning and the system's generation of the corresponding form take about a second, even for an untrained user.

Another communication mode the system allows for is called: What would hagoen if syntactic modifications? "I'his mode allows the user to perform certain transformations such as passive voice or pronominalization. In the latter case, the system will ask the user to sjecify which element he wants prononinalized (the boy, the girl, or both). Assume that, starting from the conceptual structure underlying sentence (a), the user wants to pronominalize respectively the agent, the object, and finally both arguments. In these cases he would get the following outputs :

$$
\begin{array}{ll}
\text { It regarde la fille. } & \text { (lic watches the girl) } \\
\text { I, e gatcon la regarde. } & \text { (the boy watches her) } \\
\text { Il la regarde. } & \text { (lic watches her) }
\end{array}
$$

By exploring and contrasting the differcut possibilities, the user is meant to learn how variations of meaning are reflected in form.

\section{Discussion}

We have described a computerized learning environment that has several interesting features : (a) it allows a potential user to learn French on his own. (b) it fosters loarning through exploration (hypothesis-testing, inductive learing); (c) it allows the user to ask questions rather than simply answer them. As he knows best what his needs are, he is most likely to ask the right questions at the right moment;

On the other hand, the system has also various shortcomings: (a) the linguistic coverage is extremely small : only very simple structures can be used; (b) the conceptual interface is a surface - rather than a deep. structure component (it already contains the lexical items, i.c., the program thinks in terms of the target language); (c) the size of the discourse universe : one can only talk about a very limited range of facts; (d) the rigidity of the conceptual component : the order in which the meaning is conveyed is defined a priori. The choice of verbs always precedes the choice of the nouns; (e) the terminology used (metalanguage) may be inaccessible to the linguistically innocent user.

In the remainder of this paper we will only be concented with the last point. More precisely, we will focus on the problem of conveying the notions of time, tense and aspect. For a proposal of how to increase the power and flexibility of the conceptual componcit sec $[33,34]$.

\section{Sentence generation and tense specification}

While much attention has been devoted to the problent of representing and interpreting tense [2, 13, 13a, 13b], little, if any attention laas been devoted to the problem of generating teuse in the context of natural language generation. A notable exception is the work of V. Ehrich [6] who describes the properties of a situation (a convenient neutral term for making indiscriminately reference to events, actions, processes, states) in terms of category, aspect, relation, and position.

Sentence generation consists of translating a conceptual structure into a surface form. Obviously, information concerning time, tense and aspect is part of the 
conceptual input. The problem is in what terms a naive user could communicate these abstract notions.

\subsection{The problem of choosing the right form}

Tense can be communicated by choosing among a set of metalinguistic terms (past, present, future, etc.). These terms are actually used in schools, in text books and even in intelligent tutoring systems $[7,8]$. Yet this approach has several shortcomings :

(A) Students are not linguists. While notions such as "past, present, future" seem to be meaningful when we deal with simple tenses, things change rapidly as soon as we move to more complex tenses like present continuous, past perfect, etc. The student is certainly short of intuition when he comes across tenses for which there is no equivalent in his mother tonguc.

(B) There is no one-to-one correspondance between grammatical tenses and semantic values. The "present forms" are quite often used in order to convey the meaning of the past, the present, or the future (1-4). In a similar vein, past forms can be used with a present value (5)

1) J'arrive à l'instant. (I have just arrived.) PAST;

2) Je reflechis. (I'm thinking.) PRESLNT;

3) J'arrive dans un instant. (I'm coming right now.) FUTURE:

4) J'arrive. (I just arrived.) PAST', - (I am coming.) FUTURE.

5) Je venais vous demander une augmentation

(I just wanted to ask for a salary increase) PRESEN;;

(C) The possibility of using a certain form depends on the context of the sentence (presence of a temporal adverbial, nature of the subject and complements). ${ }^{7}$ Consider the following examples:

6) Je suis content ( $l$ am very glad.);

7) * J'étais content (I was glad.);

8) *ai été content. (I have been glad.);

9) Hier, j'étais content. (Yesterday, I was very glad.);

10) Hier, jai été content. (Yesterday, I have been glad.);

11) Hier, j'ai été content d'apprendre don retour (Yesterday. I was glad to learn that you were coming back).

While (6) is quite acceptable, its translations into past be it the simple past (7), or past perfect (8),- need an explicit reference. Moreover, the form of the past perfect in French can only be used if one refers to an event, the ingression of a state,-- as in (11).

\section{How to visualize tense ?}

Icons provide a very natural way of representing tense. Several grammars for English [21] and for French [10] make use of them. We draw on these sources and adapt them for SWIM. In order to do so we provide the user with a basic sct of clements for translating tense into icons: (a) a time axis; (b) a representation of the point of speech (NOW) on the time axis; (c) a set of types of

7 When using a specific tense one should also be sensitive to the kind of inferences the addressee might draw. For instance, the following two sentences have completely different implications. : (a) I've been thinking about you. (b) I thought about you. While (a) suggests that one cares for the person one is talking to, (b) implies that one doesn't care any more. (We owe this example to Nicolay Vazov from the university of Sofia) situations (state, event, etc.); (d) a frame of reference (a window); and/or (e) a point of reference.

The time axis represents the intuitive notion of time as an oriented linear structure. The time of vertical arc locates the time of utterance: on the left hand side is the past, on the right the future. The situation to be referred to can be communicated by choosing an icon from a set of alternatives (see figure 7). The last two components, the frame and the point of reference represent the way (point of view) the speaker looks at the situation.

We start by describing these basic elements and illustrate their use through examples. We then explain how these elements are related to form a coherent metalinguistic vocabulary.

\subsection{The basic elements}

The minimal machinery necessary for generating tense is composed of a time axis with a point of speech (now) and a means of locating an action/event with respect to this point of speech (Figure 5).

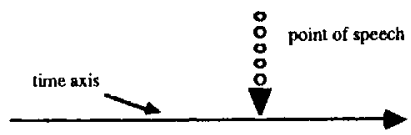

Figure 5

Reichenbach used the following concepts to characterize tense: a point of speech (S), a point of reference (R) and a point of event (E) ${ }^{8}$ Furthermore he used two kinds of connectors in order to express the fact that two events coincide with one another (","), or that an event preceded another ("-"). The following formulas shall illustrate his classification.
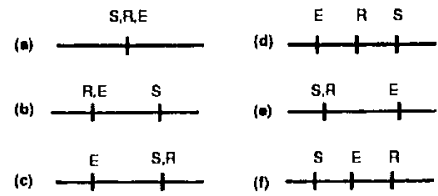

Figure 6
(a) $\mathrm{S}, \mathrm{R}, \mathrm{E}$
present tense
simple past
I see Paul
(b) $R, E \_S$
(c) E,_,R
(d) E_R S
(c) $S, R+E$ present perfect past perfect simple future
(f) S_E_R future perfect
I saw Paul
I have seen Paul
I had seen Paul
I will see Paul
I will have seen Paul

Since then the system has been extended or re-interpreted by a number of authors $[3 a, 12 a, 12 b, 24,24 a, 25 a, 28 a]$.

(A) Types of siluation and corresponding icons: A sentence refers to some point in time (temporal situation). A situation will be represented by any of the following icons

8 point: of speech refers to the very moment in which the utterance takes place (now). The point of reference is the perspective from which the event is considered. The point of event is the very moment at which the event took place (yesterday). 


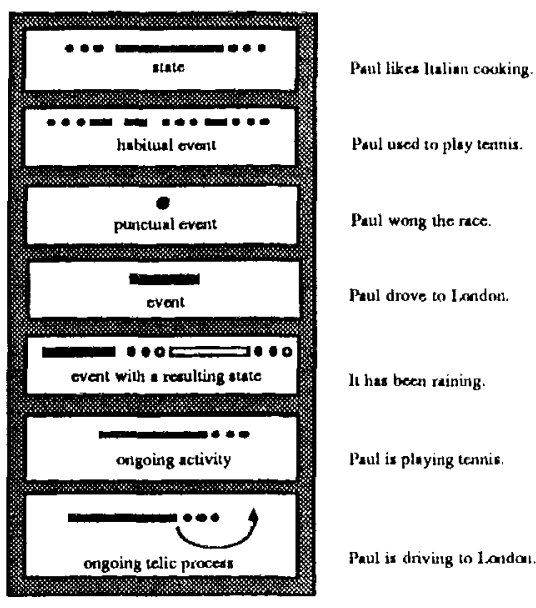

Figure 7 : Types of situation and corresponding icons

A state is considered as covering a stretch of time with no definite boundaries. The icon reperesenting this suggests this open-endedness by having fuzzy delimiting zones. Both ongoing processes and activities have a well-defined starting point but no determined point of termination. Note however, that activities can be interrupted at any time and be reported as events. Let us suppose that "Paul was swimming", and then stopped. This can be reported by *Paul swam*. Telic processes do not have this property, because they have some natural point of completion. If «Paul was swimming across the Channel, and then stopped swimming, we could describe this situation as Paul has been swimming, but we could not say «Paul swam across the Channel." In that case, the point of completion can be referred to, even if it is never reached: "Paul was swimming across the channel, but he never made it». The situation can also be considered as indeterminate: „Paul was swimming across the Channel when I last heard about hims.

An $e$ vent has both a starting point and a point of termination. It can be punctual or not. According to Reichenbach it is represented as a point or an interval, whereas we allow for the additional use of a frame. An event can also be considered with regards to the result of its occurrence. There are events with a resulting state. In the corresponding icon, we represent this state as adjacent to the event which has brought it about. Usually, the precise nature of this resulting state needs to be inferred (cf. [10]): It has been raining; in consequence the pavement is wet, it got colder, there are puddles in the street, my hairdress is spoiled, etc.

Habitual events are an undetermined number of events. The icon of habitual events is meant to suggest their resemblance to states. It should also be noted that the number of events may be conceptually indefinite. Compare: (a)I played tennis many times last year.(b) $I$ used to play tennis when I was a young man

In first case we are dealing with a sequence of individual events, not with a habitual event. Hence it is quite possible to continue the dialogue by asking the following question "how many times did you play?". while this question seems quite odd in the second case.

(B) Frame of reference, point of reference: Optional clements are a frame of reference and a point of reference, both of which can be manipulated by the user. The former consists of a window which represents the period of time considered by the speaker. It is usually associated with a temporal adverbial (Yesterday Paul visited the Eiffel Tower). The point of reference can be used in order to represent some instant which plays the role of a translated point of speech (In 1980 Paul had already visited Paris twice.).

\subsection{Using these elements to produce a time scenario}

The procedure is as follows: (a) Choose a suitable type of situation (icon) to represent the temporal structure of the situation; (b) Position the icon relative to the point of speech; (c) If necessary, introduce and position a frame and/or point of reference and position it.(d)In the overall representation, some part of the situation should be adjacent to, or included in an element of reference (point of speech, point of reference, frame of reference). If not, rcexamine step (c).

Suppose we have an untensed representation of : $\ll P a u l$ aime la cuisine italienne (P'aul likes Italian cooking). I" order to generate the tense, we choose a state and the position of the point of speech on the time axis (Figure 8a). From this representation the corresponding time (present tonse) can be generated.

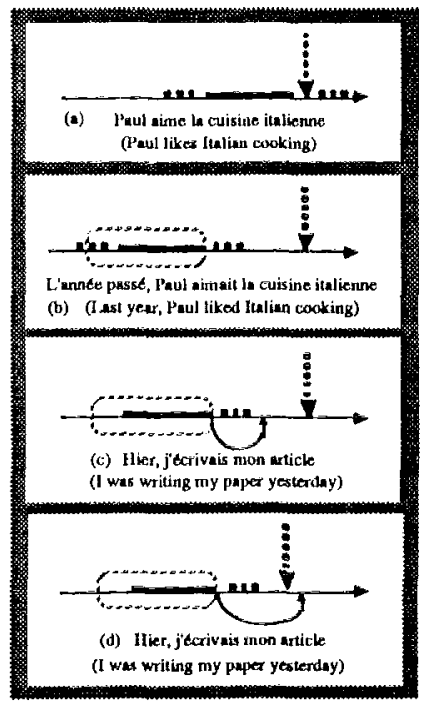

Figure 8

Figure $8 \mathrm{~b}$ conveys the sane message as $8 \mathrm{a}$ in the past. Since no direct reference to the point of speech is available, a frame of reference is necessary. Here it plays the same role as the point of speech in figure 8a. If the user adds the adverbial «l'an passe» (last year) as a marker of reference, we get «l'an passé, Paul aimait la cuisine 
italienne* (Last year Paul liked italian cooking.) The interpretation of *aimer la cuisine italiennes(to like italian cooking) in terms of a siate should be distinguished from its interpretation as an event. The latter would be the instantaneous change from one state to another. That's why we need further specifications: "Quand Paul a rencontré Gina, il a aimé la cuisine ilalienne.* (When Paul met Gina, he began to like Italian cooking). Figures $8 \mathrm{c}$ and 8d show two possible representations of similar, yet different situations. The completion of the work is not precisely determined in this case.

Among the difficulties faced by a learner of French is the dual value of "passé compose". Consider, (Hier), j"ai écrit mon article - ( (yesterday) I wrote my paper) In one interpretation (figure 9a), the writing of the paper is considered as a past event. Locating the action within a reference frame requines the use of an adverbial like "hier» (yesterday).

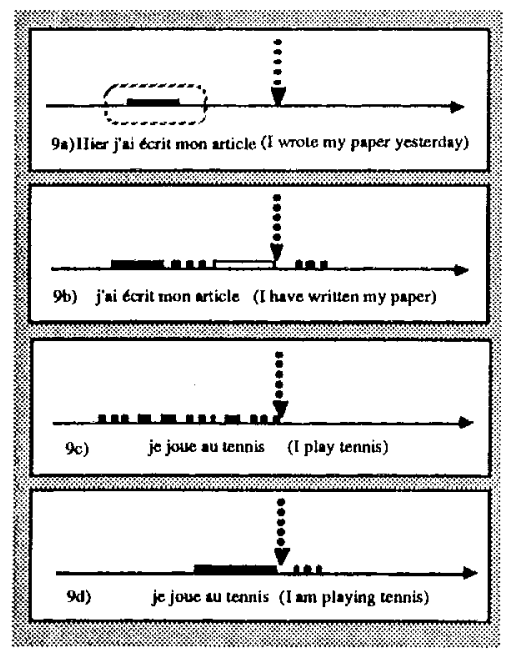

Figure 9

This case is to be differentiated from the situation depicted in Figure 9b. Here the implicit reference is now.

The past event is considered with respect to the state resulting from it (present relcvance). In fact, the same tense is used in this case in French, whereas "Yesterday I wrote my paper* would be used in English in case (9a), and $\alpha /$ have written my paper in case (9b).

Another typical case of ambiguity is the use of the "present tense" in French. The Figures 9c and 9d, while different in English, yield the same form in French. The first one $(9 \mathrm{c})$ signals habitual or repetitive use of the present tense, corresponding to "I play tennis». The second situation corresponds to "I am playing rennis", implying an ongoing activity at the time of specch. Please note that the first situation does not imply any actual activity at the time of speech, but only a general validity of a kind of property. As the icon suggests, it looks very much like a state.
6. The underlying temporal ontology and its use for generation

\subsection{Types of situation and corresponding icons}

Our classification of types of situation (cf. also [2]) is based on conceiving the temporal structure of a situation as a result of (a) the lexical meaning, the tense and the aspect of a given verb, (b) the nature of the subject, the complements and the time adverbials.

Lexical meaning : We basically subscribe to Vendler's typology [26] who classifies situations in terms of states, activities, accomplishments and achievements. Nakhimovsky, in a more recent classification [17], introduces additional features (generic vs. specific resources for atclic processes) to Vendler's punctuality, stativity, and telicity. Our classification is based on four classes of lexical meanings, corresponding to combinations of the features: punctuality, stativity, telicity.

- punctual events (punctual, non stative, atelic);

- states (non punctual, stative, atelic);

- telic processes.

- atelic activities:

Aspect is related to the perspective from which a given situation is vicwed. Following Comric [4], we distinguish between perfect, perfective and imperfective aspect. In French, the imparfait (continuous past) is a typical imperfective form: a situation is considered from the inside. Perfective, on the other hand, considers a situation as a whole, Perfect is related to the consideration of a given event together with a new state which is a consequence of this event happening, for example, I have prepared some coffee.

In our system, perfect is represented by an event with a resulting state. Aspect plays a dual role: it determines the type of situation and it allows for choosing a specific frame of reference.

Lexical meaning combined with the aspect of the verb, the types of the subjects and complements, and the temporal adverbials yield the type of situation. For example, the verb écrire (to write) has an intrinsic lexical meaning : atclic activity. However, it can change :

Paul écrivit un roman (John wrote a novel) : telic process; Paul ecrit des romans (John writes novels) : atelic activity; Paul écrivait un roman (John was writing a book) : ongoing process.

\subsection{How to choose the right tense?}

The following table shows how tense could be computed on the basis of an iconic representation of a situation. The system determines the position of the main part of the situation relative to the point of speech (PS). The qualification is necessary only in the case of an event with a resulting state, where the event is the main part of the situation.

If the main part of the situation is posterior to the point of speech, a future tense is chosen by default, though present tense remains a possible candidate. Using either or amounts to communicating a special modal nuance. 


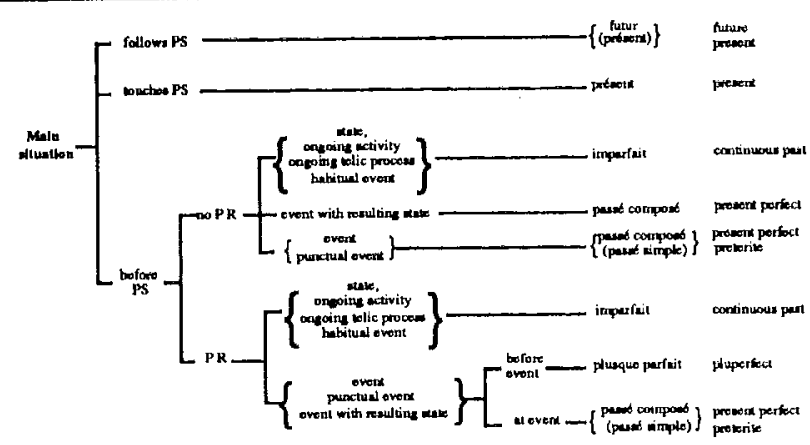

Table 1

If the main situation is prior to the time of specch, the conclusion depends on the presence of a point of reference (PR) prior to the time of speech. If no such point is

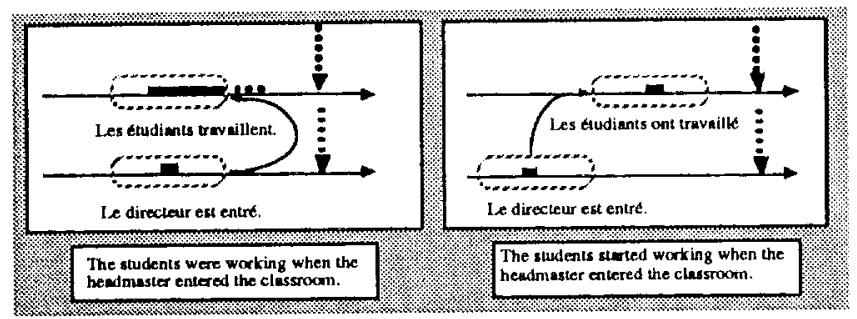

Figure 10

specified, and if the type of situation is an event, one can use the past perfect. In the case of an event or a punctual event, the past perfect is a stylistic alternative (polished style).

Temporal adverbials are classified as (a) time-position adverbs (last night, on Monday); (b) as span and duration adverbs (for a month, up to 1979); or (c) as frequency adverbs (usually, often). Temporal adverbs constrain tense generation. Durational adverbs may enforce a habiual meaning on verbs having an intrinsic punctual meaning: «He has been diving for several months now.»

Temporal subordinate clauses: In the case of simple sentences, the task of determining the tense from an icon is straightforward. More subtle strategies are needed in sentences with temporal subordinate clauses 9 . Suppose the main clause concerns «students working" (PAST), whereas the subordinate clause is «the headmasier entering the classroom (PAST). Let the temporal conjunction be quand (when). Then we have two possibilities:

9 We leave aside the problem of generating subordinate clauses in the subjunctive mood; many temporal conjunctions (e.g. avant que : before) requirc the use of the subjunctive mood.
(1) Quand le directeur est entré dans la classe, les etudiants travaill. aient (When the headmaster entered the classroom, the students. were working );

(2) Quand le direcleur est entré dars la classe, les etudiants ont travaille (When the headmaster entered the classroom, the studenis began to work).

\section{See figure 10}

The first case represents an ongoing process or activity, with an event occuring somewhere in the middle of it, while the second is a sequence of two adjacent cvents. So far we handle the case of quand (when), using icons and strategies similar to the ones described by Moens \& Stecdman [16].

The way in which temporal subordinate clauses reflect on the types and order of the situations has been examined in the literature $([24,15,16])$.

\section{Conclusion}

We have presented in this paper a method of visualizing time, tense and aspect. By using icons we have provided the user with an interface that allows him to translate abstract thought into concrete thought. The advantage being that his thoughts are expressed in terms of concrete actions rather than in terms of a (meta)language, which is often too abstract to be meaningful to the native user.

\section{References}

[1] Allen J. F., Maintaining Knowledge about Temporal Intervals, Communications of the ACM 26 (11), 1983, 832-843.

2] Bestougeff H., Ligozat G., Outils logiques pour te traitement du temps, Masson, Paris, 1989.

[3] CL88, Special Issue on Tense and Aspect, Computational Linguistics 14 (2), 1988.

[3a] Borillo, M., Vieu, L.. Eléments pour la formalisation du raisonnement spatio-temporel naturel, Congrès RFIA, AFCET, (1989)

[4] Comrie B., Aspecd, Cantbridge University Press, 1976.

[5] Dowty D. R., The Effects of Aspectual Class on the Temporal Structure of Discourse: Semantics or Pragmatics?; Linguistics and Philosophy $9 \mathrm{NI}$ (1986) $37-61$.

[6] Ehrich V., The Generation of Tense, in Natural Language generation, Gerard Kempen (ed.), 424-440, 1987, Martinus Nijhoff Publishers, Dordrecht.

[7] Fum D., P. Giagrandi \& C. Tasso, ET: an Intelligent Tutor for Foreign Language Teaching. In : Proceedings of $7 \mathrm{TS}-88$, Montreal, Canada, 1988 
[8] Fum, D.; P. Giagrandi \& C. Tasso, Tense generation in an Intelligent Tutor for Foreign Language Teaching: some Issues in the Design of the Verb Expert. In Proceedings of the 4th Conference of the European Chapter of the Association for Computational Linguistics, Manchester, UK, 1989

[9] Grasso E., Lesmo L., Lombardo V., Maccario P.M., Salato R., Terenziani P., Semantic Interpretation of Tense. Actionality and Aspect. Proceedings of the 9 th European Conference on Artificial Intelligence (ECAl-90), Stockholm, August 1990, 320-325.

[10] Grévisse M., Précis de Grammaire Françaisc, Duculot, 1979

[11] Hinrichs E., Temporal anaphora in discourses of English; Linguistics and Philosophy $9 N /$ (86) 6382.

[12] Hinrichs E., A Compositional Semantics of Temporal Expressions in English, in:Proceedings of the25th Annual Meeting of the Association for Compulational Linguistics, 6-9 July 1987, Stanford, $8-15$.

[12a] Hornstein, N., Towards a Theory of Tense, Linguistic Inquiry 8, 521-557, (1977)

[12b] Hornstein, N., As Time Goes By. Tense and Universal grammar, MIT Press (1990)

[13] Ligozat, G., Weak Representations of Interval Algebras, Proceedings of the $8 \mathrm{th}$ Conference on Arificial Intelligence, (AAAI-90), 1990, Boston, 715-720.

[13a] Ligozat, G., On generalized interval calculi, Proceedings of the $9 \mathrm{th}$ Conference on Artificial Intelligence, (AAAI-91), 1991, Anaheim, CA, 234. 240

[13b] Ligozat, G. \& Bestougeff, H., Reasoning about temporal knowledge, in Klein, E., Pouradier, F \& Wagner, K.H. (eds.) Betricbslinguistik und Linguistikbetrieb, Niemeyer, Tubingen, 1991, pp. 83-94

[14] McDermott D., A Temporal Logic for Reasoning about Processes and Plans, Cognitive Science 6, 101-155, 1982.

[15] Moens M., Steedman M., Temporal Ontology in Natural Language, in: Proceedings of the25th Annual Meeting of the Association for Computational Linguistics, 6-9 July 1987, Stanford., 1-7.

[16] Moens M., Steedman M., Temporal Ontology and Temporal Reference, in [CL88], 15-28.

[17] Nakhimovsky A., Aspect, Aspectual Class, and the Temporal Structure of Narrative, in [CL88], 29-43.

[18] Nerbonne J., Reference Time and Time in Narration; Linguistics and Philosophy $9 \mathrm{~N} /$ (1986) 63-82.

[19] Passonneau R. J., Situations and intervals, in:Proceedings of the25th Annual Meeting of the Assaciation for Computational Linguistics, 6-9 July 1987, Stanford, 16-24.

[20] Passonneau R.J., A Computational Model of the Semantics of Tense and Aspect, in [CL88], 44-60.

[21] Quirk R., Greenbaum S., Leech J., Svartvik J., A Comprehensive Grammar of the English Languagc. Longman, London and New York, 1983.

[22] Reichenbach H., Elements of Symbolic Logic. The Free Press, New York, 1966.
[23] Rohrer C. (ed), Time, Tense, and Quantifiers, Proceedings of the Stutgart Conference on the logic of tense and quantification, Niemeyer, Tubingen, 1980.

[24] Smith C., A Speaker-based Approach to Aspect; Linguistics and Philosophy 9 N I (1986) 97-115.

[24a] Smith, C., The syntax and interpretation of temporal expressions in English, Linguistics \& Philosophy 2. 1, 43-99 (1978).

[24b] Smith, C., A Theory of Aspectual Choice, Language 53, 3, 1983).

[25] Sowa J., Conceptual structures : Information Processing in Mind and Machine, Addison-Wesley, Reading, Massachusetts, 1984

[25a] van Eynde, $F$., The Semantics of Tense and Aspect, in: Proceedings of EAIA-90, 2nd Advanced School in Artificial Intelligence, Natural Language Processing in Artificial Inselligence, Filgueiras M., Damas L., Moreira N., Tomas A.P. (eds.) (1990).

[26] Vendler Z., Verbs and Time, in: Vendler Z., Linguistics in philosophy, 97-121, Cornell University Press, lthaca, New York, 1967 (Revised version of Vendler $Z$., Verbs and times, The Philosophical Review 66 , 1957, 143-60).

[27] Webber B.L., The Interpretation of Tense in Discourse, in:Proceedings of the25th Annual Meting of the Association for Compulational Linguistics, 6-9 July 1987, Stanford, 147-154.

[28] Webber B.L.. Tense as Discourse Anaphor, in [CL88], 61-73.

[28a] Yip, K. M. K., Tense, Aspect and the Cognitive representation of Time, in: Proceedings of IJCAI-85, $806-814$ (1985).

[29] Zock, M., If you can't open the Black Box, Open a Window ! or, how to Visualize Dependency Relationships when Mapping Meaning onto Form ?, In: COGNTTVA-90, Madrid

[30] Zock, M., How to Transform a Black Box into a Glass Box? or, Why use Intermediate Structures in Computer Assisted Language Learning, In: Proceedings of the 7th Annual Apple European University Consorium, Paris

[31] Zock, M. \& Laroui, A., Visualising results of choices in language generation: the use of intermediate structures. In: Proceedings of the Workshop on Natural Language Leaming. IJCAI-91, Sidney

[32] Zock, M., SWIM or Sink : the Problem of Communicating Thought. In $M$. Swarlz \& M. Yazdani (Eds.) The Bridge to International Communication: Intelligent Tutoring Systems for Foreign Language Learning, Springer Verlag, Berlin, New York, 1992

[33] Zock, M., Natural Languages are Flexible Tools, that's what Makes them Hard to Learn, to Explain and to Use. In, M. Zock \& G. Sabah (Eds.), Advances in Natural Language Generation, coedition Pinter, London - Ablex, N.J.

[34] Zock, M. \& R. Mitkov, How to ask a foreigner questions without knowing his language : propositions for a conceptual interface to communicate thought. In, Proceedings of the Natural Language Processing Pacific RIM Symposium, Singapore 